\title{
DUAL ROLES OF THE MINERAL METABOLISM DISORDERS BIOMARKERS IN PREVALENT HEMODILYSIS PATIENTS: IN RENAL BONE DISEASE AND IN VASCULAR CALCIFICATION
}

\author{
DVOSTRUKA ULOGA POREMEĆAJA BIOMARKERA METABOLIZMA MINERALA \\ KOD PREVALENTNIH BOLESNIKA LEČENIH HEMODIJALIZOM: \\ U BOLESTI KOSTIJU I U VASKULARNIM KALCIFIKACIJAMA
}

\author{
Marko Baralić1, Voin Brković1,2, Vesna Stojanov ${ }^{2,3}$, Sanja Stanković4 ${ }^{4}$ Nataša Lalić4, \\ Petar Đurić ${ }^{5}$, Ljubica Đukanović2 ${ }^{2}$ Milorad Kašiković6, Milan Petrović ${ }^{2,3}$, \\ Marko Petrović1, Milan Stošović1, Višnja Ležaić1,2 \\ ${ }^{1}$ Clinical Centre of Serbia, Department of Nephrology, Belgrade, Serbia \\ ${ }^{2}$ School of Medicine, University of Belgrade, Belgrade, Serbia \\ ${ }^{3}$ Clinical Centre of Serbia, Department of Cardiology, Belgrade, Serbia \\ ${ }^{4}$ Clinical Centre of Serbia, Centre for Medical Biochemistry, Belgrade, Serbia \\ ${ }^{5}$ Clinical Department for Renal Diseases, Zvezdara University Medical Center, Belgrade, Serbia \\ ${ }^{6}$ Clinical Centre of Serbia, Centre for Radiology and Magnetic Resonance, Belgrade, Serbia
}

\section{Summary}

Background: Vascular calcification (VC) is highly prevalent in dialysis (HD) patients, and its mechanism is multifactorial. Most likely that systemic or local inhibitory factor is overwhelmed by promoters of VC in these patients. VC increased arterial stiffness, and left ventricular hypertrophy. Thus, the present study aimed to investigate the association of VC and myocardial remodeling and to analyze their relationship with VC promoters (fibroblast growth factor 23-FGF23, Klotho, intact parathormon-iPTH, vitamin D) in 56 prevalent HD patients (median values: age 54 yrs, HD vintage 82 months).

Methods: Besides routine laboratory analyzes, serum levels of FGF 23, soluble Klotho, iPTH, 1,25-dihydroxyvitamin D3; pulse wave velocity (PWV); left ventricular (LV) mass by ultrasound; and VCs score by Adragao method were measured.

Results: VC was found in $60 \%$ and LV concentric or eccentric hypertrophy in 50\% patients. Dialysis vintage (OR 1.025 95\%Cl 1.007-1.044, $\mathrm{p}=0.006$ ) FGF23 (OR 1.006, 95\%

\section{Kratak sadržaj}

Uvod: Kalcifikacije krvnih sudova (VC) su prisutne kod velikog broja bolesnika lečenih dijalizom (HD), a njihov nastanak je uslovljen različitim mehanizmima. Postoji mišljenje da promoteri VC prevazilaze lokalni ili sistemski uticaj inhibitora VC kod ovih bolesnika. VC povećavaju krutost krvnih sudova i izazivaju hipertrofiju leve komore (LVH). Ova studija je imala za ciljeve da ispita povezanost VC i remodelinga srčanog mišića i da analizira ulogu promotera VC (fibroblast growth factor 23-FGF23, Klotho, intakt parathormon-iPTH, vitamin D) kod 56 prevalentnih HD bolesnika (medijana: starost 54 godine, HD trajanje 82 meseca).

Metode: Pored rutinskih laboratorijskih analiza, izmereni su FGF 23, Klotho, iPTH, 1,25-dihidroksi vitamin D; brzina pulsnog talasa (PWV); LVH pomoću sonografije; a skor VC je određen Adragao metodom.

Rezultati: VC su nađene kod $60 \%$ a koncentrična i ekscentrična LVH kod 50\% bolesnika. Trajanje HD (OR 1,025, p= 0,006 ), FGF23 (OR 1,006, $p=0,029$ ) i S-magnezijum (OR $0.000, p=0,04)$ bili su udruženi sa VC. Promene u geome-

Address for correspondence:

Višnja Ležaić

School of Medicine,

University of Belgrade,

Pasterova 2, 11000 Belgrade, Serbia,

Tel 381638639554

e-mail: visnjalezaic@gmail.com 
$\mathrm{Cl} 0.992-1.012, \mathrm{p}=0.029)$ and serum magnesium (OR $0.000,95 \% \mathrm{Cl} 0.000-0.214, \mathrm{p}=0.04)$ were associated with VC. Changes in myocardial geometry was associated with male sex (beta $=-0.273,95 \% \mathrm{Cl}-23.967$ 1.513, $\mathrm{p}=0.027$ ), iPTH (beta 0.029, 95\%Cl $-0.059-0.001$, $\mathrm{p}=0.027$ ) and vitamin $\mathrm{D}$ treatment (beta $25.49,95 \% \mathrm{Cl}$ 11.325-39.667, $p=0.001)$. Also, patients with the more widespread VC had the highest LV remodeling categories. PWV was associated patient's age, cholesterol, diastolic blood pressure, LV mass (positively) and serum calcium (negatively), indicating potential link with atherosclerotic risk.

Conclusions: Despite to different risk factors for VC and myocardial remodeling, obtained results could indicate that risk factors intertwine in long-term treatment of HD patients and therefore careful and continuous correction of mineral metabolism disorders is undoubtedly of the utmost importance.

Keywords: hemodialysis, vascular calcifications, myocardial remodeling, FGF23, Klotho

\section{Introduction}

Patients with end-stage renal disease (ESRD) are at high risk of cardiovascular (CV) morbidity and mortality (1). Besides traditional risk factors (hypertension, diabetes mellitus, obesity, dyslipidemia, smoking, physical inactivity), CKD-related risk factors were found to amplify the mechanisms of CV disease development. The CV burden in ESRD patients includes accelerated atherosclerosis and arteriosclerosis with stiff and noncompliant arteries, and a high prevalence of cardiomyopathy characterized by left ventricular hypertrophy $(\mathrm{LVH})$ and ventricular stiffness (1). Vascular calcifications (VC) have been also recognized as an important risk factor for cardiovascular disease in hemodialysis (HD) patients (2), representing a significant predictor of both all-cause and cardiovascular mortality (3). The hemodynamic consequences of VC include loss of arterial elasticity, development of $\mathrm{LVH}$, decrease in coronary artery perfusion and myocardial ischemia (4-5).

The pathogenesis of $\mathrm{VC}$ has been the subject of many studies in which an association with mineral metabolism disorders and renal bone disease was found (6). The process presents as a series of complex biochemical and cellular events in which a number of regulatory proteins that promote or inhibit the deposition of minerals in the blood vessels participate actively $(3,6,7)$. Thus, systemic or local inhibitory factors of VC, such as matrix Gla protein, fetuin-A, osteopontin, osteoprotegerin and pyrophosphate, are most likely overwhelmed in CKD patients by promoters (calcium and phosphate abnormalities, extreme serum PTH levels, excess administration of calcium salts, inflammation, malnutrition and oxidative stress) that induce vascular smooth muscle cell damage and death. This leads to an undesirable imbalance favoring excessive calcification (7). Several factors and mechanisms underlying the development of $\mathrm{VC}$ in triii miokarda su bile udružene sa muškim polom (beta $=$ $0,273, p=0,027$ ), iPTH (beta $0,029, p=0,027)$ i lečenjem sa vitaminom $D$ (beta $25,49, p=0,001$ ). Bolesnici sa većim VC skorom imali su najviše kategorije LVH. PWV je bila udružena sa starosti bolesnika, koncentracijom holesterola, dijastolnim krvnim pritiskom i LVH (pozitivno) i S-kalcijumom (negativno).

Zaključak: lako su različiti faktori rizika za VC i promene u geometriji miokarda, dobijeni rezultati bi mogli da ukažu na međusobno preplitanje ispitanih faktora kod bolesnika lečenih hemodijalizom. Zbog toga se savetuje pažljiva i stalna korekcija poremećaja u metabolizmu minerala

Ključne reči: hemodijaliza, kalcifikacije krvnih sudova, remodelovanje miokarda, FGF23, Klotho

patients with CKD have been put forward. Besides increased serum levels of calcium and phosphate as the main promoters of calcification, many other factors such as lipids, glucose intolerance/diabetes, uremic toxins, C-reactive protein (CRP) may be involved and have been investigated $(7,8)$.

Moreover, fibroblast growth factor 23 (FGF23) and its co-receptor, Klotho have emerged as key regulators of mineral homeostasis. A bone derived hormone (9), FGF23 regulates phosphate reabsorption in renal proximal tubules, inhibits production and increases metabolism of 1,25-dihydroxyvitamin $D$ $(1,25(\mathrm{OH}) 2 \mathrm{D})$, and is associated with regulation of parathyroid hormone (PTH) by Klotho dependent and independent pathways (9). Besides influences on phosphate flux (10) Klotho also exhibits several other protective effects against cell senescence, apoptosis and VC (11).

Serum FGF23 levels rise early and exponentially in CKD prior to any detectable increase in serum phosphate and PTH level (12). Contrary to this, poor renal function negatively affects Klotho levels with detectable reduction starting from CKD stage 2. An increase in FGF23 with Klotho deficiency has been reported to promote $\mathrm{VC}$ and arterial stiffness in experimental studies (13). However, data observed for humans have not uniformly demonstrated these correlations.

The aim of the present study was to investigate the association of $\mathrm{VC}$ and vascular wall function with left ventricular mass and structure and to analyze their relationship with promoters of VC (FGF23, Klotho, PTH, vitamin D) in prevalent hemodialysis patients. 


\section{Materials and Methods}

The study involved 56 patients with ESRD on $\mathrm{HD}$ selected from the pool of patients treated with chronic hemodialysis in the Department of Nephrology, Clinical Center of Serbia. Patients were enrolled if they (1) had been on HD for at least 6 months; (2) agreed to participate in the study, which was approved by the institutional review board; (3) did not have acute CV complications during the 6 months preceding entry into the study; (4) had no hemodynamically significant lower extremity artery occlusive disease; and (5) did not present with atrial fibrillation at the time of pulse wave velocity (PWV) measurement. The patients were monitored for up to 28 months. The Ethics Committee of the Clinical Center of Serbia, evaluated and approved this study (decision No 1690/21, June 9, 2015), and all patients provided written informed consent.

Standard bicarbonate hemodialysis sessions lasted for 12 hours weekly. Dialysate calcium (dCa) concentration was individualized to meet the specific requirements of patients by optimizing management of serum $\mathrm{Ca}$, phosphate, PTH and alkaline phosphatase. The dialysate calcium concentration was chosen as follows: $\mathrm{dCa}$ of $1.5 \mathrm{mmol} / \mathrm{L}$ was commonly used; $\mathrm{dCa}$ at $1.25 \mathrm{mmol} / \mathrm{L}$ permitted the administration of vitamin D supplements and Ca-based phosphate binders in the setting of biochemically suspected adynamic bone disease; dCa was raised to 1.75 $\mathrm{mmol} / \mathrm{L}$ to suppress hyperparathyroidism, having in mind its side effects. Management of renal osteodystrophy also depended on drug availability. Before beginning this cross sectional study the patients had used paricalcitol for 12 to 22 months, except for two subjects who had received the drug for 4 months and 80 months, respectively. In addition, some patients had taken sevelamer for no longer than 12 months. Cinacalcet was given for up to 6 months to only a few patients. Sevelamer and cinacalcet were not used at the start of the study and in the subsequent period.

\section{Biochemical analyses}

The following laboratory data were recorded: serum levels of urea, creatinine, uric acid, total protein, CRP, lipid profile, phosphate, calcium, alkaline phosphatase, iPTH, as well as hematological analyses, iron status, mean standard weekly $\mathrm{Kt} / \mathrm{V}$ and urea reduction ratio (URR). We also determined 1,25-vitamin D3, FGF 23 and soluble Klotho.

The routine biochemical parameters were measured by standard laboratory techniques. An immunoradiometric assay was used to measure iPTH (ELSAPTH, CIS bio International) and normal values are 11 to $62 \mathrm{pg} / \mathrm{mL}$. Serum levels of FGF23 were assayed with a commercially available kit (Cusabio, USA) using ETI-max 3000 (Dia-Sorin). According to the manufacturer's package insert, the measurement range is $3.12-200 \mathrm{pg} / \mathrm{mL}$ with a lower limit of detection of $0.78 \mathrm{pg} / \mathrm{mL}$. Intra-assay precision was $<8 \%$, and inter-assay precision $<10 \%$. Serum levels of soluble Klotho were assayed with a commercially available kit (Cusabio, USA) using ETI-max 3000 (DiaSorin). According to the manufacturer's package insert, the measurement range is $0.156 \mathrm{ng} / \mathrm{mL}-10$ $\mathrm{ng} / \mathrm{mL}$ with a lower limit of detection of 0.039 $\mathrm{ng} / \mathrm{mL}$. Intra-assay precision was $<8 \%$ and interassay precision $<10 \%$. Serum $1,25(\mathrm{OH}) 2 \mathrm{D}$ was determined with a commercial chemiluminescent immunoassay (DiaSorin S.p.A., Italy) using the LIAISON ${ }^{\circledR}$ Analyzer (Diasorin S.p.A., Italy ). The measuring range was $7.6-147.8 \mathrm{ng} / \mathrm{mL}$, the limit of quantification was $3.5 \mathrm{ng} / \mathrm{mL}$ and intra- and inter-assay coefficients of variation were between $2.5 \%$ and $6.5 \%$.

\section{Vascular calcifications}

Vascular calcification in the iliac, femoral, radial and digital arteries in plain radiographic films of pelvis and hands were evaluated by one person. A simple VC score was calculated as described by Adragao et al. (14). In brief, the pelvis radiographic films were divided into four sections by two imaginary lines: a horizontal line over the upper limit of both femoral heads and a median vertical line over the vertebral column. Films of the hands were divided by a horizontal line over the upper limit of the metacarpal bones for each hand. The presence of linear calcifications in each section was counted as 1 and absence as 0 . The final score was the sum of all the sections, ranging from 0 to 8 , whereby $0=$ no calcification, $1-3=$ mild calcification, $>4=$ severe calcification.

\section{Cardiovascular evaluation}

Cardiac structure was assessed by echocardiographic examination using VIVID 7 (General Electric Medical Systems, Horten, Norway) by one experienced cardiologist blinded to the clinical data of the study patients. Two-dimensional and two-dimensionally guided $M$-mode images were recorded from the standardized views according to the American Society of Echocardiography recommendations (15). Interventricular septal wall thickness in diastole, left ventricular internal diameter in diastole, and left ventricular posterior wall thickness in diastole were measured in the left parasternal long-axis view. Left ventricular mass (LVM), index of LVM (iLVM) and relative wall thickness (RWT) were calculated on-line and categorized according to the recommendations (16). The following categories of iLVM were recorded: iLVM inside the reference range, and mildly, moderately and severely abnormal indices. RWT allows further classification of LVM increase as either concentric hypertrophy (RWT > 0.42) or eccentric hypertrophy (RWT $\leq 0.42$ ). 
Pulse wave velocity (PWV) was assessed using the Complior SP system (Artech Medical, Pantin, France) utilizing two sensors (1 carotid and 1 femoral) simultaneously to determine the velocity of the pulse wave in relation to the distance between the femoral artery and the suprasternal notch (17). A directly measured PWV $>12 \mathrm{~m} / \mathrm{s}$ cutoff was used according to previously published reference values (18), together with the corresponding association with adverse $\mathrm{CV}$ events as determined.

Ankle brachial index $(\mathrm{ABI})$ values were determined 10-30 min before $\mathrm{HD}$ with an $\mathrm{ABI}$-form device that automatically and simultaneously measured blood pressure in both arms and ankles using a Doppler device (19). Briefly, occlusion and monitoring cuffs were placed tightly around the upper arm without blood access and on both lower extremities with the patient in a supine position. The ABI was calculated from the ratio of the ankle systolic blood pressure divided by the arm systolic blood pressure. $A B I$ measurements were done twice for each patient. Low $A B I$ $(<0.9)$ identifies obstructive artery disease, while high $\mathrm{ABI}(>1.3)$ is caused by stiff non-compressible distal arteries, probably connected with distal artery calcification (20).

Additional variables of interest from patients' files were: systolic and diastolic blood pressures recorded during dialysis, demographic data (age, gender), co-morbidities (diabetes, hypertension, cardiac diseases: ischemic heart disease, heart failure, cerebrovascular accident, and other chronic diseases), and underlying kidney disease, dialysis duration, previous parathyroidectomy, treatment used (antihypertensives, phosphate binders, vitamin D, erythropoietin stimulating agents-ESA).

\section{Statistical analysis}

Descriptive data are presented as the mean (SD) for normally distributed variables and as median (IQR) for non-normally distributed variables. Categorical variables are expressed as absolute numbers with percentages. Univariable regression analysis was used to evaluate the relation of various demographic, clinical and biochemical variables with vascular wall characteristics, and indices of myocardial remodeling. Pearson's correlation and linear logistic regression models were used to assess association between PWV, $A B I, i L V H$ and RWT and other parameters. Binary logistic regression analysis for VS (VS score $0=0$ and score 1-8 =1) was used to predict the odds ratio (OR) of being a case based on the values of the independent predictors. Since the number of variables showing events was small, and there was significant correlation between some independent variables, several models were used in logistic regression analyses. The models were assembled so that the number of combining independent variables was in line with the number of events and the variables between which there was significant correlation were not combined. All statistical analyses were performed using SPSS version 21 (SPSS, Inc, Chicago, IL, USA). A p-value $\leq 0.05$ was considered statistically significant.

\section{Results}

The study included 56 prevalent hemodialysis patients ( 29 men) of mean age $54 \pm 13$ years (range 29 - 79 years). The mean duration of HD was 82 months ( $M$, IQ 31-170.5). Causes of CKD were diabetes mellitus ( 6 patients or $10.7 \%$ ), hypertension (11 patients or $19.6 \%$ ), glomerular disease (7 patients or $12.5 \%)$, cystic kidney disease (7 patients or $12.5 \%$ ), renal calculosis (12 patients or 21.4\%), Balkan endemic nephropathy (2 patients or 3.6\%) and other diseases (11 patients or 19.6\%). Subtotal parathyroidectomy was performed in 11 patients before enrolment, and all patients had received surgery 5 to 18 years previously except for one who had had an operation a year before the study started.

Baseline biochemical parameters and treatment at enrolment are shown in Table I. Hypocalcemia was present in $35.7 \%$ patients and hyperphosphatemia in $58.9 \%$, among whom 16 individuals had serum phosphate levels above $2.0 \mathrm{mmol} / \mathrm{L}$. The median iPTH was $115.5 \mathrm{pg} / \mathrm{mL}$, with an IQ range between 38 and $341.8 \mathrm{pg} / \mathrm{mL}$. Analysis of individual values showed that more than half of the patients $(33 / 59 \%)$ had iPTH lower than $150 \mathrm{pg} / \mathrm{mL}$ and among them three patients had previously undergone partial parathyroidectomy. The median alkaline phosphatase value was inside the reference range but seven patients had higher and two patients lower levels than the reference values. Low concentrations of circulating 1,25D were found in 25 patients. Median FGF23 concentration was above the upper reference value, i.e. 812 $\mathrm{pg} / \mathrm{mL}$ (IQR 333-1500). Moreover, median circulating Klotho was $0.039 \mathrm{ng} / \mathrm{mL}$ (IQR 0.028 - 0.066) which is below the reference value. Most subjects were treated with oral phosphate binders. Thus, 75\% of the patients received calcium-containing phosphate binders and $5.3 \%$ of them were given the noncalcium-containing phosphate binder, lanthanum carbonate. Vitamin D (calcitriol, 7 patients) or vitamin D analogues (paricalcitol, 11 patients; alphacalcidol, 5 patients), alone (6 patients) or in combination with phosphate binders (17 patients) were given to $41 \%$ of the participants depending on the laboratory results for minerals.

Data on arterial and myocardial parameters for our patients are presented in Table II. Vascular calcifications were not found in $38.6 \%$ of prevalent patients treated with hemodialysis, while an Adragao score above 4 was present in $38.6 \%$ of them (three individuals had the highest Adragao score, i.e. 8). The number of patients with VC score 8 increased with longer 
Table I Baseline biochemical parameters at the enrolment of the study.

\begin{tabular}{|c|c|c|}
\hline & $\begin{array}{c}\bar{x} \pm S D \\
\text { Median }(25-75 \mathrm{IQ})\end{array}$ & Reference values \\
\hline $\begin{array}{l}\text { Calcium, number (\%): } \\
<2.15, \mathrm{mmol} / \mathrm{L} \\
>2.65, \mathrm{mmol} / \mathrm{L}\end{array}$ & $\begin{array}{c}2.2(2.07-2.3) \\
20(35.7 \%) \\
2(3.5 \%)\end{array}$ & $2.15-2.65 \mathrm{mmol} / \mathrm{L}$ \\
\hline $\begin{array}{l}\text { Phosphate, number (\%): } \\
>1.55(>2.0), \mathrm{mmol} / \mathrm{L}\end{array}$ & $\begin{array}{c}1.7 \pm 0.4 \\
33-58.9 \%(16=28.5 \%)\end{array}$ & $0.8-1.55 \mathrm{mmol} / \mathrm{L}$ \\
\hline Alkaline phosphatase, $U / L$ & $70(52-96.2)$ & $40-120 \mathrm{U} / \mathrm{L}$ \\
\hline $\begin{array}{l}\text { ¡PTH, } \mathrm{pg} / \mathrm{mL} \\
\text { number }(\%) \text { : } \\
<150 \\
>600\end{array}$ & $\begin{array}{c}115.5(38-341.8) \\
33(58.9 \%) \\
9(16.0 \%)\end{array}$ & \\
\hline $\begin{array}{l}1,25 \text { dihydroxyvitamin } \mathrm{D}, \mathrm{ng} / \mathrm{mL} \\
\text { number }(\%) \text { : } \\
<20 \\
20-30 \\
>30\end{array}$ & $\begin{array}{l}36.7 \pm 19.1 \\
10(17.8 \%) \\
15(26.7 \%) \\
31(55.3 \%)\end{array}$ & $7.6-147.8 \mathrm{ng} / \mathrm{mL}$ \\
\hline $\begin{array}{l}\text { FGF 23, pg/mL } \\
\text { number }(\%): \\
<200 \\
>200 \\
>1000 *\end{array}$ & $\begin{array}{c}812(333-1500) \\
7 \\
49(87.5 \%) \\
25(44.6 \%)\end{array}$ & $3.12-200 \mathrm{pg} / \mathrm{mL}$ \\
\hline $\begin{array}{l}\text { Klotho, } \mathrm{ng} / \mathrm{mL} \\
\text { number }(\%) \text { : } \\
25 \% \text { Percentiles } \\
\text { M } \\
75 \% \text { Percentiles }\end{array}$ & $\begin{array}{c}0.039(0.028-0.066) \\
19(33.9 \%) \\
21(37.5 \%) \\
16(28.6 \%)\end{array}$ & $0.156-10 \mathrm{ng} / \mathrm{mL}$ \\
\hline $\begin{array}{l}\text { Treatment: yes } \\
\text { Vitamin D } \\
\text { Phosphate binders } \\
\text { Calcium based } \\
\text { Non calcium based } \\
\text { ESA } \\
\text { Anti hypertensive drugs }\end{array}$ & $\begin{array}{l}23(41 \%) \\
42(75 \%) \\
3(5.3 \%) \\
33(58.9 \%) \\
33(58.9 \%)\end{array}$ & \\
\hline
\end{tabular}

* out of patients with FGF23 > $200 \mathrm{pg} / \mathrm{mL}$

$\mathrm{ESA}=$ erythropoietin stimulating agents

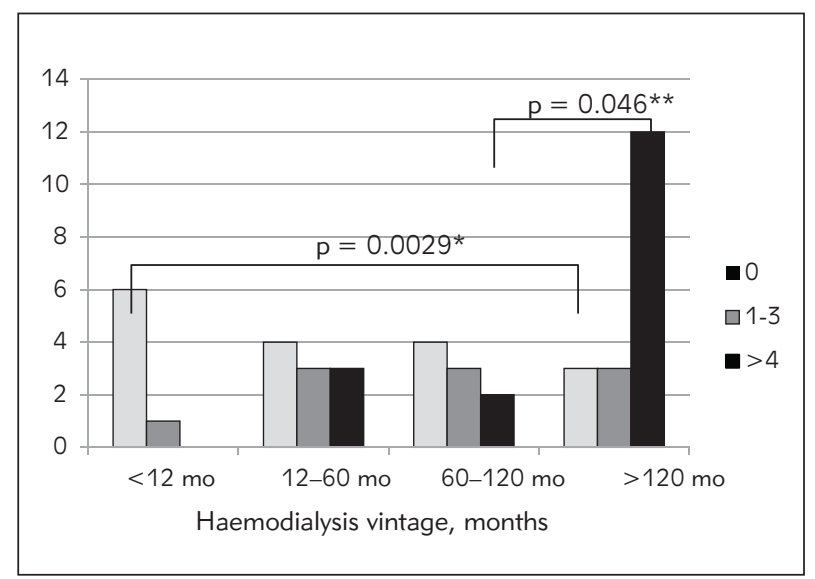

Figure 1 Frequency of vascular calcifications estimated by Adragao score depending of dialysis vintage.

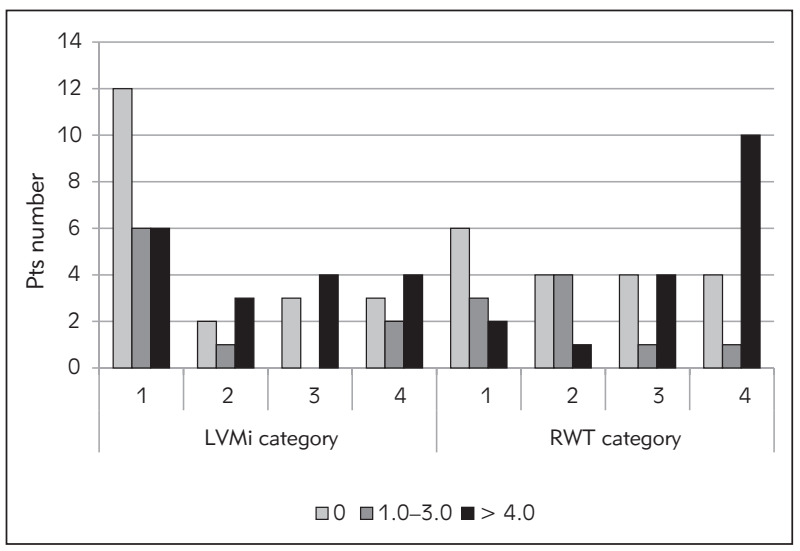

Figure 2 Frequency of index of left ventricular mass and of relative wall thickness (RWT) categories depending of vascular calcification (Adragao) score (significance of differences are given in text). 
Table II Arterial and hemodynamic parameters in studied hemodialysis patients.

\begin{tabular}{|c|c|}
\hline & $\begin{array}{l}\bar{x} \pm S D \text { or median } \\
(25-75 \mathrm{IQ})\end{array}$ \\
\hline $\begin{array}{l}\text { Adragao score, number }(\%) 0 \\
1-3 \\
>4\end{array}$ & $\begin{array}{l}22(38.6 \%) \\
12(22.7 \%) \\
22(38.6 \%)\end{array}$ \\
\hline $\begin{array}{l}\mathrm{PWV}, \mathrm{m} / \mathrm{s} \\
\text { Number }(\%) \\
\mathrm{PWV}>12\end{array}$ & $\begin{array}{c}8.6(7.525-10.03) \\
5(8.9 \%)\end{array}$ \\
\hline $\begin{array}{l}\mathrm{ABI} \text {, number }(\%) \\
\quad<0.9 \\
\quad>1.3\end{array}$ & $\begin{array}{l}1.18 \pm 0.17 \\
1(0.02 \%) \\
7(12.5 \%)\end{array}$ \\
\hline iLVM, $\mathrm{g} / \mathrm{m}^{2}$ & $109.1 \pm 23.3$ \\
\hline $\begin{array}{l}\text { Categories iLVM, number (\%): } \\
\text { reference range } \\
\text { mildly abnormal } \\
\text { moderately abnormal } \\
\text { severly abnormal }\end{array}$ & $\begin{array}{c}29(51.8 \%) \\
8(14.3 \%) \\
9(16.1 \%) \\
10(17.8 \%)\end{array}$ \\
\hline RWT & $393 \pm 78.9$ \\
\hline $\begin{array}{l}\text { Categories RWT, number (\%): } \\
\text { normal geometry } \\
\text { concentric remodeling } \\
\text { concentric hypertrophy } \\
\text { eccentric hypertophy }\end{array}$ & $\begin{array}{c}15(26.7 \%) \\
12(21.5 \%) \\
9(16.1 \%) \\
20(35.8 \%)\end{array}$ \\
\hline
\end{tabular}

iLV $M=$ index of left ventricular mass, $\mathrm{PWV}=$ pulse wave velocity, $\mathrm{ABI}=$ ankle-brachial index, $\mathrm{RWT}=$ relative wall thickness

Table III Association of vascular score with demographic data and biochemical variables determined with multivariate logistic regression analysis (binary).

\begin{tabular}{|l|c|c|c|c|c|c|}
\hline \multirow{2}{*}{$\begin{array}{l}\text { Dependent } \\
\text { variable }\end{array}$} & $\begin{array}{c}\text { Independent } \\
\text { variables }\end{array}$ & OR & B & p & \multicolumn{2}{|c|}{$95 \% \mathrm{Cl}$ for B } \\
\hline Adragao score & Dialysis vintage & 1.025 & 0.025 & 0.006 & 1.007 & 1.044 \\
& Magnesium & 0.000 & -12.627 & 0.04 & 0.000 & 0.214 \\
& FGF23 & 1.006 & -0.004 & 0.029 & 0.992 & 1.012 \\
\hline
\end{tabular}

Adragao score as binary variable: score 0 denoted as 0 and score $1-8$ as 1

hemodialysis duration (Figure 1). Significantly fewer patients dialyzed for more than 120 months had VC 0 , compared with those receiving dialysis for less than 12 months ( $p=0.0029$ ) and vice versa. Namely, relatively more patients dialyzed for more than 120 months had VC score 8 in comparison to the number dialyzed for less than 120 months $(p=0.0052)$ or to patients dialyzed for 12-60 months ( $p=0.046)$. The median PWV was $8.6 \mathrm{~m} / \mathrm{s}$, while $8.9 \%$ of our patients had a PWV >12 m/s. The mean $A B I$ was within the reference range, but every fifth patient showed some abnormality, i.e. higher than 1.3 or lower than 0.9 . Half of the studied patients had iLVM inside the reference range, but a severely abnormal iLVM was revealed in $18 \%$ of them. However, many $(73 \%)$ of our patients manifested different abnormal categories of $\mathrm{LV}$ remodeling, and among them $35.8 \%$ had eccentric hypertrophy. In addition, patients with more widespread VC had the highest LV remodeling categories, and the differences are statistically significant (Figure 2). In other words, in comparison to patients with VC 0, patients with a VC score $>4$ had both concentric and eccentric LVH more frequently ( $p=$ $0.035)$. The same was true for patients with VC score $1-3$ ( $p=0.0085)$. In addition, patients with VC score above 4 exhibited more eccentric hypertrophy in comparison to patients with score $0(p=0.041)$ or score 1-3 ( $p=0.0183)$.

In multivariable binary logistic regression analysis, VC was significantly associated with dialysis vintage and FGF23 positively, but with magnesium negatively (Table III). In multivariable linear regression analysis PWV was associated with patient's age, cholesterol, diastolic blood pressure, iLVM and RWT (positively) and serum calcium (negatively), while $A B I$ was correlat- 
Table IV Association of PWV, ABI and iLVM with demographic data and biochemical variables determined with multivariate linear regression analysis.

\begin{tabular}{|c|c|c|c|c|c|}
\hline $\begin{array}{l}\text { Outcome } \\
\text { variable }\end{array}$ & $\begin{array}{l}\text { Independent } \\
\text { variable }\end{array}$ & B & $\beta$ & $\mathrm{p}$ & $95 \% \mathrm{Cl}$ \\
\hline \multicolumn{6}{|l|}{ PWV } \\
\hline & $\begin{array}{l}\text { Age } \\
\text { Cholesterol } \\
\text { sCa } \\
\text { Diastolic BPiLVMRWT }\end{array}$ & $\begin{array}{l}0.069 \\
0.661 \\
-4.296 \\
0.0514 \\
0.027 \\
0.008\end{array}$ & $\begin{array}{l}0.372 \\
0.295 \\
-0.342 \\
0.447 \\
0.275 \\
0.282\end{array}$ & $\begin{array}{l}0.013 \\
0.045\end{array}$ & $\begin{array}{ll}0.015 & 0.124 \\
0.008 & 1.314 \\
-7.375 & 1.216 \\
0.026 & 0.077 \\
0.004 & 0.050 \\
0.001 & 0.015\end{array}$ \\
\hline \multicolumn{6}{|l|}{$A B I$} \\
\hline & $\begin{array}{l}\mathrm{Hb} \\
\text { Uric acid }\end{array}$ & $\begin{array}{l}0.0044 \\
-0.0006\end{array}$ & $\begin{array}{l}0.314 \\
-0.307\end{array}$ & $\begin{array}{l}0.017 \\
0.019\end{array}$ & $\begin{array}{cc}0.001 & 0.008 \\
-0.001 & 0.000\end{array}$ \\
\hline \multicolumn{6}{|l|}{ iLVM } \\
\hline & $\begin{array}{l}\text { Sex } \\
\text { iPTH } \\
\text { Treatment with vit D }\end{array}$ & $\begin{array}{l}-12.740 \\
0.0294 \\
25.496\end{array}$ & $\begin{array}{l}-0.273 \\
-0.298 \\
0.544\end{array}$ & $\begin{array}{l}0.027 \\
0.027 \\
0.001\end{array}$ & $\begin{array}{l}-23.967-1.513 \\
-0.0590 .001 \\
11.32539 .667\end{array}$ \\
\hline \multicolumn{6}{|l|}{ RWT } \\
\hline & $\begin{array}{l}\text { Sex } \\
\text { Age } \\
\text { Hemoglobin } \\
\text { Phosphate } \\
\text { iPTH } \\
\text { Treatment with vit D }\end{array}$ & $\begin{array}{l}-47.88 \\
1.946 \\
-2.033 \\
-50.512 \\
0.195 \\
-55.648\end{array}$ & $\begin{array}{l}-0.296 \\
0.341 \\
-0,322 \\
-0.276 \\
0.583 \\
-0.351\end{array}$ & $\begin{array}{l}0.048 \\
0.039 \\
0.032 \\
0.043 \\
0.001 \\
0.033\end{array}$ & $\begin{array}{l}-95.3-0.464 \\
0.1013 .791 \\
-3.884-0.181 \\
-99.455-1.569 \\
0.0820 .307 \\
-106.7314 .566\end{array}$ \\
\hline
\end{tabular}

ed with hemoglobin concentration and uric acid, iLVM was associated with male sex and treatment with vitamin D (positively) and iPTH (negatively), and RWT was associated with male sex, age and iPTH (positively) and phosphate, hemoglobin concentration and treatment with vitamin $\mathrm{D}$ (negatively) (Table $\mathrm{M}$ ).

\section{Discussion}

This study showed that a considerable number of prevalent hemodialysis patients had damage to both peripheral artery walls and geometry of the myocardium. Evaluated by plain radiography, VC was found in almost $60 \%$ of the studied patients, and $50 \%$ of them had left ventricular concentric or eccentric hypertrophy. Arterial wall functional damage, measured with PWV and $A B I$, was less frequently present in the studied group, i.e. in five and eight patients, respectively.

The frequency of cardiovascular damage in our patients is similar to values already reported for prevalent hemodialysis or peritoneal dialysis patients (4).

When evaluating the most common changes, VC and myocardial remodeling did not share similar risk factors. Thus, according to our analyses, VC score was independently associated with dialysis vintage and FGF23 (positively) and magnesium (negatively). Changes in geometry of the myocardium i.e. iLVM and
RWT were independently associated with patient's sex (males), iPTH and vitamin D treatment. In addition patient's age and hemoglobin concentration were selected as independent predictors of RWT. Nevertheless, patients with more widespread VC expressed the highest LV remodeling categories, and the differences are statistically significant. In other words, in comparison to patients with VC 0, patients with VC score $>4$ had concentric or eccentric LVH more frequently ( $p=$ 0.035). The same was true for patients with VC score $1-3$ ( $p=0.0085$ ). Our data are in accordance with previous studies reporting an association between VC in HD patients and dialysis vintage, serum magnesium and FGF23 concentration. Many reports have underlined the significance of dialysis vintage on the development and progression of VC (21-23). In the study of Goldsmith and colleagues involving 38 patients on hemodialysis for 10-25 years, radiographic VC prevalence increased from 39\% at dialysis onset to $92 \%$ after average dialysis duration of 16 years. Calcification severity also increased with vintage (23).

Over the last decade, an increasing number of investigations have demonstrated a close relationship between serum magnesium concentration and CV disease risk in the general population and ESRD patients (24). There is evidence that magnesium insufficiency is a pro-atherogenic factor involved in endothelial dysfunction, atherosclerosis, and vascular 
calcification (24). However, the precise mechanisms and their contribution to cardiovascular protection remain unclear but two mechanisms have been proposed: first, magnesium may bind phosphate and delay calcium phosphate crystal growth in the circulation, thereby passively interfering with calcium phosphate deposition in the vessel wall; and second, magnesium may regulate vascular smooth muscle cell transdifferentiation towards an osteogenic phenotype by active cellular modulation of factors associated with calcification (24).

It was reported that FGF23 concentrations are often 100-1000 fold above the normal range in CKD patients and increases as CKD progresses to ESRD (26). In our study, serum FGF23 levels were elevated in most patients but particularly in those with a high VC score. Also, FGF23 appeared as the only mineral metabolism-related factor independently associated with VC. Our results are in accordance with earlier findings for CKD and dialysis patients (12,27-29). Contrary to this, the study of 1,500 patients with CKD stages 24 enrolled in the Chronic Renal Insufficiency Cohort (CRIC), failed to detect an association of FGF23 with coronary or thoracic aorta calcification and this was supported by the results of an experimental investigation carried out at the same time (30). However, hyperphosphatemia was strongly associated with prevalence and severity of coronary artery calcification independent of FGF23. The authors suggested that FGF23 and hyperphosphatemia are independently involved in VC pathogenesis in CKD patients.

Previous studies have demonstrated that VC is closely associated with serum levels of calcium, phosphate and calcium phosphate product $(4,21)$. High serum phosphate levels might be considered as a 'vascular toxin' (31). Phosphorus is a stimulant of osteochondrogenic differentiation and apoptosis of vascular smooth muscle cells, which is also related to upregulation of the expression of the growth arrestspecific gene 6 product and its receptor (32). Furthermore, clinical studies have shown that patients with the poorest phosphate control have the most rapid progression of VC (32). In our study hyperphosphatemia was found in 33 (59\%), hypocalcemia in 20 (36\%) and dysregulation of PTH in 42 (75\%) patients. Despite such a high frequency of calcium, phosphate and $\mathrm{PPTH}$ disorders, no influence on VC was found. However, VC does not only develop as the consequence of a wide range of different biological processes, but also owing to pharmacological interventions. Patients included in the present analysis were dialyzed for a minimum of 20 months (median 82 months, IQ 31-170.5) before our analysis. During the dialysis vintage, plus the period of CKD prior to dialysis, cardiovascular changes would have been developing due to various metabolism disorders associated with chronic renal failure but the influence of pharmacological interventions cannot be overlooked. In the period preceding the study, treatment options in Serbia were limited, especially phosphate binders.
Most patients were, and still are treated with calcium containing phosphate binders, which have been associated with progressive coronary artery and aortic calcification (33). Serum PTH levels outside the target guideline range were found in a large number of our patients. Thus, nine patients had iPTH above the upper limit and 33 below the lower limit of KDOQI for iPTH (34). Over-suppression of PTH can be explained by excessive calcium load (through treatment) or by parathyroidectomy. Elevated iPTH leading to high turnover bone disease and low PTH, a risk factor causing low bone turnover, can augment VC development and progression $(35,36)$. In the present crosssectional study, association between the various variables and VC was observed at one point, but not with the particular metabolic disorders and therapeutic interventions undertaken. However, the time spent on $H D$, which includes all such events was selected as a significant independent predictor of VC. Nevertheless, it may be assumed that FGF23, as a key regulator of mineral homeostasis, connected with all previous disorders, was singled out here as a variable significantly associated with VC.

Many studies reported association between PWV and VC $(37,38)$. We failed to find this relationship but PWV above the cut off value of 12 was detected in only five patients and all of them had the highest VC score of 8 . Multivariate linear regression analysis found that PWV was associated with both traditional cardiovascular risk factors, including patient's age, diastolic blood pressure and LVMI, and with nontraditional risk factors such as serum calcium and cholesterol levels, suggesting a potential link between atherosclerotic risk and arterial stiffness in hemodialysis patients. Our results are in line with previous data that pathological PWV can be expected in older hemodialysis patients. Ferreira and coworkers reported that almost $37 \%$ of their 278 dialysis patients had pathological PWV, which was strongly associated with age. They recommended that if an ESRD patient younger than 60 years has PWV $>12$, that is of critical relevance for early intervention guidance (39).

The myocardial structure results presented here showed that besides patient's sex, LV remodeling was associated with $\mathrm{iPTH}$ and treatment with vitamin $\mathrm{D}$. This means that the lower the $\mathrm{iPTH}$, the greater the $\mathrm{LVH}$. Moreover, our patients treated with vitamin D had higher categories of LV abnormalities i.e. concentric and eccentric LVH. All these results contrast with previously published data. PTH is one of the uremic factors that have been implicated in the pathogenesis of LVH and cardiac dysfunction in CKD patients. Myocardial cells are affected by PTH via specific receptors on the membrane. In addition, an experimental study indicated that PTH induced cardiac interstitial fibrosis through the permissive activation of cardiac fibroblasts (40). Many clinical studies have also demonstrated a relationship between high values of PTH and LVH (41). This is supported by an intervention study finding showing that calcimimetics successfully lowered serum PTH levels, followed by 
improved cardiac function and less LVH (42). The reverse relationship between $\mathrm{PPTH}$ and iLVM found in our study could be explained by the higher prevalence of patients with low than with high serum iPTH level. No studies have yet proved that low iPTH causes or is involved in myocardial remodeling. Concentric and eccentric LVH in our patients with low iPTH was most likely the result of an earlier episode of secondary hyperparathyroidism, which was then treated either medically or by parathyroidectomy.

Different findings have been obtained about the effect of vitamin $D$ therapy on myocardial geometry. While many experimental studies have demonstrated that vitamin D can prevent progression of cardiac hypertrophy and have cardio-protective properties (43), others failed to show such a positive influence on LV mass, including the PRIMO study (44) and OPERA trial (45). However, the results of further analysis showed that significantly fewer patients in the vitamin D-treated group were hospitalized for CVD compared to the placebo group. Moreover, their left atrial diameter and serum brain natriuretic peptide levels were lower (46). Our results are in accordance with the former and indicated that patients treated with vitamin $\mathrm{D}$ had major disorders in myocardial structure. Since there are many confounding factors in clinical settings, further detailed investigation is needed.

Among the promoters of $\mathrm{VC}$ examined here, associations of FGF23 with VC and iPTH with myocardial remodeling were found. On the other hand, a significant number of our patients had low Klotho and vitamin D concentrations, and disturbed serum calcium and phosphate levels. Having in mind that FGF23, Klotho, iPTH, and 1,25-dihydroxyvita$\min \mathrm{D}$ are basic regulators of phosphorus metabolism, one could speculate that, although the abnormalities of both minerals and PTH were not selected as risk factors for $\mathrm{VCs}$ or PWV, they might have favored VC frequency in our patients. Similar speculations about additional risk factors could be applied to myocardial remodeling. According to the published data, elevated circulating values of FGF23 have been linked to cardiovascular disease in patients with all stages of CKD. Thus, recent experimental data have defined a direct role for FGF23 in pathological changes in cardiac myocytes, independently of changes in mineral metabolism, which led to increased prevalence of $\mathrm{LVH}$ and cardiovascular calcification in adults and pediatric patients $(47,48)$. This influence of FGF23 was not confirmed in patients on overnight hemodialysis with lower phosphate values and better clearance of uremic toxins, for whom no association between LVMI and FGF23 was found (49), indicating that the pathogenesis of LVH in dialysis patients is probably multifactorial and needs further evaluation.

Our study has some limitations. The semi-quantitative radiological Adragao score used was original and has not been validated elsewhere. The small number of patients involved may have influenced statistical signif- icances. Finally, the cross-sectional nature of our study did not give us an explanation about when VC and myocardial remodeling started during treatment of our patients, nor allow us to identify all the factors associated with cardiovascular changes, which is the main limitation of this investigation.

\section{Conclusion}

VC and myocardial remodeling are common in prevalent hemodialysis patients but different risk factors associated with them may be selected. Higher risk for VC had patients with longer dialysis vintage and higher FGF23 but lower magnesium serum levels. Changes in geometry of the myocardium i.e. left ventricular hypertrophy and RWT were independently associated with patient's sex (males), iPTH and vitamin $D$ treatment. Also, patient's age and hemoglobin level were selected as independent predictors of RWT. Nevertheless, it is obvious that factors that regulate mineral metabolism in hemodialysis patients had the main role in the formation of both VC and myocardial remodeling and therefore patients with the higher VC score had the highest LV remodeling categories. In long-term treatment of patients on hemodialysis the risk factors intertwine but careful and continuous correction of mineral metabolism disorders is undoubtedly of the utmost importance although it sometimes depends on the availability of treatment measures.

Acknowledgments. This work was conducted as a part of project No 175089 funded by the Ministry of Science, Education and Technological Development, Belgrade, Republic of Serbia.

Funding: The Society of Nephrology of the Republic of Serbia provided financial support for the laboratory analyses

Authors' contributions:

MB. collected data

VB. collected data

MP collected data

VS, MP, PDj made cardiovascular measurement

MK- made plane radiography

MS- statistical analysis

LjDj. statistical analysis, critical revision of article

VL. designed research/study, performed research/ study, collected data, analyzed data, wrote the paper

\section{Ethical approval}

Protocol of the study received approval from the local Ethic Committee in Clinical Centre of Serbia.

\section{Conflict of interest statement}

The authors stated that they have no conflicts of interest regarding the publication of this article. 


\section{References}

1. Ortiz A, Covic A, Fliser D, Fouque D, Goldsmith D, Kanbay M, Mallamaci F, Massy ZA, Rossignol P, Vanholder R, Wiecek A, Zoccali C, London GM. Epidemiology, contributors to, and clinical trials of mortality risk in chronic kidney failure. Lancet 2014; 383: 1831-43.

2. Alpdemir M, Eryilmaz M, Alpdemir MF, Topçu G, Azak A, Yücel D. Comparison of widely used biochemical analytes in the serum and saliva samples of dialysis patients. J Med Biochem 2018; 37: 346-54.

3. Schlieper G, Schurgers L, Brandenburg V, Reutlingsperger C, Floege J. Vascular calcification in chronic kidney disease: an update. Nephrol Dial Transplant 2016; 31: 31-9.

4. London GM, Guerin AP, Marchais SJ, Metivier F, Pannier $\mathrm{B}$, Adda H. Arterial media calcification in end-stage renal disease: impact on all-cause and cardiovascular mortality. Nephrol Dial Transplant 2003; 18: 1731-40.

5. Nitta K, Akiba T, Uchida K, Otsubo S, Otsubo Y, Takei T, Ogawa T, Yumura W, Kabaya T, Nihei H. Left ventricular hypertrophy is associated with arterial stiffness and vascular calcification in hemodialysis patients. Hypertens Res 2004; 27: 47-52.

6. London GM, Marty C, Marchais SJ, Guerin AP, Metivier F, de Vernejoul MC. Arterial calcifications and bone histomorphometry in end-stage renal disease. J Am Soc Nephrol 2004; 15: 1943-51.

7. Ketteler M, Rothe H, Krüger T, Biggar PH, Schlieper G. Mechanisms and treatment of extraosseous calcification in chronic kidney disease. Nat Rev Nephrol 2011; 7: 509-16.

8. Zoccali C, London G. Con: Vascular calcification is a surrogate marker, but not the cause of ongoing vascular disease, and it is not a treatment target in chronic kidney disease. Nephrol Dial Transplant 2015; 30: 352-7.

9. Liu S, Quarles LD. How fibroblast growth factor 23 works. J Am Soc Nephrol 2007; 18: 1637-47.

10. Kawata T, Imanishi Y, Kobayashi K, Miki T, Arnold A, Inaba $M$, Nishizawa Y. Parathyroid hormone regulates fibroblast growth factor-23 in a mouse model of primary hyperparathyroidism. J Am Soc Nephrol 2007; 18: 2683-8.

11. Ikushima M, Rakugi H, Ishikawa K, Maekawa $Y$, Yamamoto K, Ohta J, Chihara Y, Kida I, Ogihara T. Antiapoptotic and anti-senescence effects of Klotho on vascular endothelial cells. Biochem Biophys Res Commun 2006; 339: 827-32.

12. Jean G, Terrat JC, Vanel T, Hurot JM, Lorriaux C, Mayor $B, C$ Chazot $C$. High levels of serum fibroblast growth factor (FGF)-23 are associated with increased mortality in long haemodialysis patients. Nephrol Dial Transplant 2009; 24: 2792-6.

13. Jimbo R, Kawakami-Mori F, Mu S, Hirohama D, Majtan B, Shimizu Y, Yatomi Y, Fukumoto S, Fujita T, Shimosawa T. Fibroblast growth factor 23 accelerates phosphateinduced vascular calcification in the absence of Klotho deficiency. Kidney Int 2014; 85: 1103-11.

14. Adragao T, Pires A, Lucas $C$ et al. A simple vascular calcification score predicts cardiovascular risk in haemodial- ysis patients. Nephrol Dial Transplant 2004; 19: 14808.

15. Sahn DJ, DeMaria A, Kisslo J, Weyman A. Recommendations regarding quantitation in M-mode echocardiography: results of a survey of echocardiographic measurements. Circulation 1978; 58, 1072-83.

16. http://www.csecho.ca/wp-content/themes/twentyelevencsecho/cardiomath/? eqnHD=echo\&eqnDisp $=$ Ivmlvmi, page visited 12.dec 2017.

17. Asmar R, Benetos A, Topouchian J, Laurent P, Pannier B, Brisac AM, Target $R$, Levy BI: Assessment of arterial distensibility by automatic pulse wave velocity measurement. Validation and clinical application studies. Hypertension 1995; 26: 485-90.

18. Boutouyrie P, Vermeersch SJ et al. Reference Values for Arterial Stiffness' Collaboration: Determinants of pulse wave velocity in healthy people and in the presence of cardiovascular risk factors: 'establishing normal and reference values'. Eur Heart J 2010; 31: 2338-50.

19. Bailey MA, Griffin KJ, Scott DJ. Clinical assessment of patients with peripheral arterial disease. Semin Intervent Radiol 2014; 31: 292-9.

20. Panjeta M, Tahirović I, Sofić E, Ćorić J, Dervišević A. Interpretation of Erythropoietin and Haemoglobin Levels in Patients with Various Stages of Chronic Kidney Disease. J Med Biochem 2017; 36: 145-52.

21. Lumlertgul D, Kantachuvesiri S, Apichaiyingyurd S, Treamtrakanpon W, Rattanasompattikul M, Gojaseni $P$, Thanakitcharu P, Trakarnvanich T, Poonvivatchaikarn U, Vareesangthip K; Impact-CKD investigators. Prevalence of and Predictive Factor for Abdominal Aortic Calcification in Thai Chronic Kidney Disease Patients. Ther Apher Dial 2017 Dec; 21(6): 611-9.

22. Disthabanchong S, Vipattawat K, Phakdeekitcharoen B, Kitiyakara C, Sumethkul V. Abdominal aorta and pelvic artery calcifications on plain radiographs may predict mortality in chronic kidney disease, hemodialysis and renal transplantation. Int Urol Nephrol 2018; 50: 35564.

23. Čabarkapa V, Ilinčić $B$, Đerić $M$, Radosavkić I, Šipovac $M$, Sudji J, Petrović V. Screening for chronic kidney disease in adult males in Vojvodina: A cross-sectional study. J Med Biochem 2017; 36: 153-62.

24. Matias PJ, Azevedo A, Laranjinha I, Navarro D, Mendes M, Ferreira C, Amaral T, Jorge C, Aires I, Gil C, Ferreira $A$. Lower serum magnesium is associated with cardiovascular risk factors and mortality in haemodialysis patients. Blood Purif 2014; 38: 244-52.

25. Ter Braake AD, Shanahan CM, de Baaij JHF. Magnesium Counteracts Vascular Calcification: Passive Interference or Active Modulation? Arterioscler Thromb Vasc Biol 2017; 37(8): 1431-45.

26. Gutiérrez OM, Mannstadt $M$, Isakova T, Rauh-Hain JA, Tamez $\mathrm{H}$, et al. Fibroblast growth factor 23 and mortality among patients undergoing hemodialysis. N Engl J Med 2008; 359: 584-92. 
27. Lee YT, Ng HY, Chiu TT, Li LC, Pei SN, Kuo WH, Lee CT. Association of bone-derived biomarkers with vascular calcification in chronic hemodialysis patients. Clin Chim Acta 2016; 452: 38-43.

28. Desjardins L, Liabeuf S, Renard C, et al. FGF23 is independently associated with vascular calcification but not bone mineral density in patients at various CKD stages. Osteoporos Int 2012; 23: 2017-25.

29. Nasrallah MM, El-Shehaby AR, Salem MM, Osman NA, El Sheikh E, et al. Fibroblast growth factor-23 (FGF-23) is independently correlated to aortic calcification in haemodialysis patients. Nephrol Dial Transplant 2010; 25: 2679-85.

30. Scialla JJ, Lau WL, Reilly MP, et al: Fibroblast growth factor 23 is not associated with and does not induce arterial calcification. Kidney Int 2013; 83: 1159-68.

31. Kanbay M, Goldsmith D, Akcay A, Covic A. Phosphate: the silent stealthy cardiorenal culprit in all stages of chronic kidney disease: a systematic review. Blood Purif 2009; 27: 220-30.

32. Giachelli CM. The emerging role of phosphate in vascular calcification. Kidney Int 2009; 75: 890-7.

33. Yamada K, Fujimoto S, Nishiura R et al. Risk factors of the progression of abdominal aortic calcification in patients on chronic haemodialysis patients. Nephrol Dial Transplant 2007; 22: 2032-7.

34. Kidney Disease: Improving Global Outcomes (KDIGO) CKD-MBD Work Group. KDIGO clinical practice guideline for the diagnosis, evaluation, prevention, and treatment of chronic kidney disease-mineral and bone disorder (CKD-MBD). Kidney Int Suppl 2009; (Suppl 113): S1-S130.

35. Thompson B, Towler DA. Arterial calcification and bone physiology: role of the bone-vascular axis. Nature Rev Endocrinol 2012; 8: 529-43.

36. Hernandes FR, Canziani ME, Barreto FC, Santos RO, Moreira VM, Rochitte CE, Carvalho AB. The shift from high to low turnover bone disease after parathyroidectomy is associated with the progression of vascular calcification in hemodialysis patients: A 12-month follow-up study. PLoS One 2017; 12(4): e0174811.

37. Raggi P, Bellasi A, Ferramosca E, et al. Association of pulse wave velocity with vascular and valvular calcification in hemodialysis patients. Kidney Int 2007; 71: 802-7.

38. Adragao T, Pires A, Curto JD, et al. A plain X-ray vascular calcification score is associated with arterial stiffness and mortality in dialysis patients. Nephrol Dial Transplant 2009; 24: 997-1002.

39. Ferreira JP, Girerd N, Pannier B, Rossignol P, London GM. High Pulse-Wave Velocity Defines a Very High Cardiovascular Risk Cohort of Dialysis Patients under Age 60. Am J Nephrol 2017; 45: 72-81.
40. Stefenelli T, Abela C, Frank H, Koller-Strametz J, Globits S, Bergler-Klein J, Niederle B. Cardiac abnormalities in patients with primary hyperparathyroidism: implications for follow-up. J Clin Endocrinol Metab 1997; 82: 106-12.

41. Fujii H, Kim Jl, Abe T, Umezu M, Fukagawa M. Relationship between parathyroid hormone and cardiac abnormalities in chronic dialysis patients. Intern Med (Tokyo, Japan) 2007; 46: 1507-12.

42. Choi SR, Lim JH, Kim MY, Hong YA, Chung BH, Chung S, Choi BS, Yang CW, Kim YS, Chang YS, et al. Cinacalcet improves endothelial dysfunction and cardiac hypertrophy in patients on hemodialysis with secondary hyperparathyroidism. Nephron Clin Pract 2012; 122: 1-8.

43. Panizo S, Barrio-Vazquez S, Naves-Diaz M, Carrillo-Lopez N, Rodriguez I, Fernandez-Vazquez A, Valdivielso JM, Thadhani R, Cannata-Andia JB. Vitamin D receptor activation, left ventricular hypertrophy and myocardial fibrosis. Nephrol Dial Transpl 2013; 28: 2735-44.

44. Thadhani R, Appelbaum E, Pritchett Y, Chang Y, Wenger J, Tamez H, Bhan I, Agarwal R, Zoccali C, Wanner C, et al. Vitamin $D$ therapy and cardiac structure and function in patients with chronic kidney disease: the PRIMO randomized controlled trial. JAMA 2012; 307(7): 674-84.

45. Wang AY, Fang F, Chan J, Wen YY, Qing S, Chan IH, Lo G, Lai KN, Lo WK, Lam CW, et al. Effect of paricalcitol on left ventricular mass and function in CKD-the OPERA trial. J Am Soc Nephrol 2014; 25(1): 175-86.

46. Tamez H, Zoccali C, Packham D, Wenger J, Bhan I, Appelbaum E, Pritchett Y, Chang Y, Agarwal R, Wanner $C$, et al. Vitamin $D$ reduces left atrial volume in patients with left ventricular hypertrophy and chronic kidney disease. Am Heart J 2012; 164(6): 902-909 e902.

47. Faul C, Amaral AP, Oskouei B, Hu MC, Sloan A, Isakova T, Gutiérrez OM, Aguillon-Prada R, Lincoln J, Hare JM, Mundel P, Morales A, Scialla J, Fischer M, Soliman EZ, Chen J, Go AS, Rosas SE, Nessel L, Townsend RR, Feldman HI, St John Sutton M, Ojo A, Gadegbeku C, Di Marco GS, Reuter S, Kentrup D, Tiemann K, Brand M, Hill JA, Moe OW, Kuro-O M, Kusek JW, Keane MG, Wolf $M$. FGF23 induces left ventricular hypertrophy. The Journal of Clinical Investigation 2011; 121(11): 4393-408.

48. Shibata K, Fujita S, Morita H, Okamoto Y, Sohmiya K, Hoshiga M, Ishizaka N. Association between circulating fibroblast growth factor 23, alpha-Klotho, and the left ventricular ejection fraction and left ventricular mass in cardiology inpatients. PLoS One 2013; 8(9): e73184.

49. Knap B, Večerić-Haler Ž, Benedik M, Buturović-Ponikvar J, Ponikvar R, Bren AF. Fibroblast growth factor 23 and left ventricular mass index in maintenance hemodialysis patients: standard versus long nocturnal hemodialysis. Ther Apher Dial 2013; 17: 407-11. 